\title{
Mucosal Melanoma of the Head and Neck Pathologic Distant Metastasis TNM
} Finding v8

National Cancer Institute

\section{Source}

National Cancer Institute. Mucosal Melanoma of the Head and Neck Pathologic Distant Metastasis TNM Finding v8. NCI Thesaurus. Code C133175.

A pathologic finding about one or more characteristics of mucosal melanoma of the head and neck, following the rules of the TNM AJCC v8 classification system as they pertain to distant metastases. 